\title{
Autosomal recessive spastic paraplegia type 24
}

INSERM

\section{Source}

INSERM. (1999). Orphanet: an online rare disease and orphan drug data base. Autosomal recessive spastic paraplegia type 24. ORPHA:101004

A very rare, pure form of spastic paraplegia characterized by an onset in infancy of lower limb spasticity associated with gait disturbances, scissor gait, tiptoe walking, clonus and increased deep tendon reflexes. Mild upper limb involvement may occasionally also be associated. 